P-ISSN: 1979-052X

e-ISSN: 2614-6215

November 2017

\title{
PELAKSANAAN HADHĀNAH DI PANTI ASUHAN \\ BUDI MULYA, SUKARAME BANDAR LAMPUNG
}

\author{
H. Mahmudin Bunyamin \\ Dosen Fakultas Ushuluddin UIN Raden Intan Lampung \\ email: mahmudinbunyamin@yahoo.co.id
}

Diterima: 10 Juni 2017. Disetujui: 07 Oktober 2017

Dipublikasikan: November 2017

\begin{abstract}
This articel discusses the process of hadhanah at Budi Mulya orphanage, Sukarame Bandar Lampung. This research indicates that this orphanage has helped to provide stewardship and child care. They take over the parenting attitude of the child, provides all the basic needs of children: food, clothing, and boards. They also prepare formal and non-formal education and equipped them with knowledge and practice of daily worship as their provision in living the world and the hereafter. The factors that motivate caregivers to take care of the orphans are sincere devotion, community support and good infrastructure. But, they obstacle factors that are children from different backgrounds, the implementation of pesantren model not working properly, unprofessional caretakers, and unoptimal of management structure.
\end{abstract}

Keywords: Hadhānah, Panti Asuhan Budi Mulya

\begin{abstract}
A. Pendahuluan
Salah satu tujuan perkawinan adalah untuk menyambung keturunan yang kelak akan dijadikan ahli waris. Keinginan mempunyai anak bagi setiap pasangan suami isteri merupakan naluri insani dan secara fitrah anak-anak tersebut merupakan amanah Allah swt kepada suami isteri tersebut. Bagi orangtua, anak
\end{abstract}




\section{Ijtimaiyya: Jurnal Pengembangan Masyarakat Islam 10 (2) (2017)}

tersebut diharapkan dapat mengangkat derajat dan martabat orangtua kelak apabila mereka dewasa nanti, menjadi anak yang saleh dan salehah yang selalu mendo'akannya apabila dia meninggal nanti.

Berangkat dari pemikiran inilah, baik ayah maupun ibu dari anak-anak sama-sama berkeinginan keras untuk dapat lebih dekat dengan anak-anaknya agar dapat membimbing langsung dan mendidiknya agar anak-anak tersebut apabila telah dewasa nanti dapat memcapai cita-citanya. Demikian pula anak-anak yang telah lahir dari perkawinan itu, selalu ingin dekat dengan orangtuanya, karena mereka ingin selalu dilindungi dan diberikan kasih sayang oleh kedua orangtua sampai mereka mampu mandiri untuk mengarungi kehidupan ini.

Pemeliharaan anak dalam Islam disebut Hadhānah. Secara etimologis, Hadhanah berarti di samping atau berada di bawah ketiak. Sedangkan secara terminologis, Hadhanah artinya merawat dan mendidik seseorang yang belum mumayiz, atau yang kehilangan kecerdasannya, karena mereka tidak bisa memenuhi keperluan sendiri. Hadhānah (pemeliharaan anak) pada dasarnya menjadi tanggungjawab kedua orangtuanya. Hadhanah dalam hal ini meliputi berbagai hal, masalah ekonomi, pendidikan dan segala sesuatu yang menjadi kebutuhan pokok anak. Dalam konsep Islam, tanggungjawab ekonomi berada di pundak suami sebagai kepala rumah tangga. Meskipun dalam hal ini tidak menutup kemungkinan bahwa isteri dapat membantu suami dalam menanggung kewajiban ekonomi tersebut. Karena itu yang terpenting adalah adanya kerjasama dan tolong menolong antara suami dan isteri dalam memlihara anak, mengantarkan hingga anak tersebut dewasa.

Hadhānah dapat berjalan dengan baik pada rumah tangga yang tenteram dan damai. Untuk tumbuh-kembang dengan baik, seorang anak memerlukan orang yang sanggup untuk mendidiknya dan memberi perlindungan terhadapnya agar tetap tumbuh dan berkembang dengan semestinya. Faktor utama yang harus dilindungi oleh orang yang mengasuhnya adalah faktor lingkungan, karena faktor lingkunganlah yang sangat menentukan baik atau tidaknya anak. Anak akan baik apabila dijauhi dari lingkungan yang buruk, dan begitu juga sebaliknya anak tidak akan tumbuh baik apabila hidup di lingkungan yang tidak baik. 
Pada sisi yang lain yang akan menjadi fokus penelitian ini adalah proses pengasuhan anak-anak yang dititipkan di lembaga sosial yang dikenal dengan panti asuhan. Anak-anak tersebut biasa disebut anak panti. Menjadi anak panti tentu memiliki suks dukanya sendiri. Ada panti asuhan yang disinyalir hanya memanfaatkan keberadaan anak-anak asuhnya sebagai komoditi untuk mencari kekayaan belaka. Bahkan ketika ada donator yang berkunjung ke panti asuhan untuk memberikan sumbangan, mereka mengumpulkan anak-anak sekitar panti agar terkesan memiliki anak-anak asuh yang banyak.

Namun adapula panti asuhan yang dikelola dengan baik. Mereka yang tulus ikhlas mendidik anak-anak yatim piatu atau anak-anak yang berasal dari keluarga miskin untuk dididik dengan sepenuh hati. Mereka menghantarkan anak-anak asuh tersebut menjemput impiannya di masa depan yang cemerlang.

Salah satu panti asuhan yang sudah lama berdiri dan telah mendapatkan kepercayaan di tengah-tengah masyarakat di kota Bandar lampung adalah panti asuhan yang dikelola oleh Muhammadiyah. Nama panti asuhannya adalah Budi Mulya, yang terletak di jalan Madrasah, Sukarame, kota Bandar Lampung. Dalam makalah ini akan dibahas: Bagaimanakah proses Hadhānah anak-anak di panti asuhan Budi Mulya, Sukarame Bandar Lampung? Dan Apakah kendala yang dihadapi dalam melaksanakan proses Hadhānah di panti asuhan Budi Mulya, Sukarame Bandar Lampung?

Metode Penelitian dalam menjawab pertanyaan penelitian ini adalah: Jenis penelitian ini adalah Field research yang bersifat deskriptif. Penelitian ini menggunakan pendekatan normatif Hukum Islam. Teknik pengumpulan data penelitian ini melalui wawancara, observasi, dan dokumentasi. Analisa data dilakukan secara kualitatif. Penganalisaan data dilakukan secara simultan sejak proses pengumpulan data. Dan terakhir penarikan kesimpulan dilakukan secara Induktif.

\section{B. Pembahasan}




\section{Ijtimaiyya: Jurnal Pengembangan Masyarakat Islam 10 (2) (2017)}

\section{Pengertian Hadhānah}

Hadhānah berasal dari kata Hidhan artinya: lambung. dan seperti kata: Hadhānah ath-thaairu baidhahu, artinya burung itu mengepit telur di bawah sayapnya. Begitu pula dengan perempuan (ibu) yang mengepit anaknya. Ibu pengasuh disebut hadhinah sedangkan anak yang diasuh disebut mahdbum. ${ }^{1}$ di samping atau berada di bawah ketiak. ${ }^{2}$

Para ahli fiqh, mendifinisikan Hadhänah ialah melakukan pemeliharaan anak-anak yang masih kecil laki-laki ataupun perempuan atau yang sudah besar, tetapi belum mumayiz, tanpa perintah dari padanya, menyediakan sesuatu yang menjadikan kebaikannya, menjaganya dari sesuatu yang menyakiti dan merusaknya, mendidik jasmani, rohani dan akalnya agar mampu berdiri sendiri menghadapi hidup dan memikul tanggung jawabnya. Mengasuh anak-anak yang masih kecil hukumnya wajib. Sebab mengabaikannya berarti menghadapkan anak-anak yang masih kecil kepada bahaya kebinasaaan. ${ }^{3}$ Hadhānah menurut Zahabi adalah melayani anak kecil untuk mendidik dan memperbaiki kepribadiannya oleh orang-orang yang berhak mendidiknya pada usia tertentu yang ia tidak sanggup melakukannya sendiri. ${ }^{4}$

Sedangkan dalam Kompilasi Hukum Islam, Hadhānah disebutkan dalam Pasal 1 huruf (g) yaitu: Pemeliharaan atau Hadhānah adalah kegiatan mengasuh, memelihara dan mendidik anak hingga dewasa atau mampu berdiri sendiri.

Allah berfirman dalam QS at-Tahrim ayat 6:

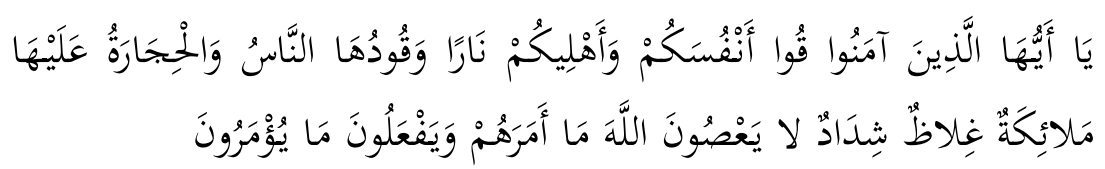

Artinya:

Hai orang-orang yang beriman, peliharalah dirimu dan keluargamu dari api neraka yang bahan bakarnya adalah manusia dan batu;

${ }^{1}$ Al-Sayid Sabiq, Fiqh al-Sunnah, (Beirut: Dar Kitab al-Arabi, 1987), h. 232

2 Abdul Azis Dahlan, Ensiklopedi Hukum Islam, (Jakarta: Ikhtiar Baru Van Hoepe, 1999), h. 415

${ }^{3}$ Ibid.

${ }^{4}$ Andi Syamsu Alam dan M. Fauzan, Hukum Pengangkatan Anak Perspekftif Islam, (Jakarta: Pena Media, 2008), h. 114. 
penjaganya malaikat-malaikat yang kasar, keras, dan tidak mendurhakai Allah terhadap apa yang diperintahkan-Nya kepada mereka dan selalu mengerjakan apa yang diperintahkan.

Ayat di atas sebagai pertanda bahwa perhatian Islam terhadap keluarga yang di dalamnya termasuk anak-anak, tidak hanya sebatas terhadap perhatian dunia, akan tetapi menyangkut tentang kemaslahatan keluarga di akhirat.

Alasan ibu diutamakan dalam Hadhānah karena dialah yang berhak untuk melakukan Hadhänah dan menyusui. Sebab dia lebih mengetahui dan lebih mampu mendidiknya. Juga karena ibu mempunyai rasa kesabaran untuk melakukan tugas ini yang tidak dipunyai oleh bapak. Ibu juga lebih punya waktu untuk mengasuh anaknya dari pada bapak. Oleh karena hal-hal ini semua, maka dalam mengatur kemaslahatan anak, ibu diutamakan. Ibu memiliki sifat lebih perasa, lebih halus, lebih kasih,lebih mesra lebih baik dan lebih sayang karena itu lebih berhak terhadap anaknya, selama ia belum kawin lagi. Hal ini yang merupakan sebab-sebab bagi ketetapan hukum bahwa ibu lebih berhak terhadap anaknya yang masih kecil.

Imam al-Gazali menegaskan di Kitab Ihya' Ulumiddin bahwa salah satu tujuan pernikahan adalah untuk mendapatkan keturunan yang baik. ${ }^{5}$ Oleh karena itu, langkah memperoleh dua tujuan ini, terutama tujuan kedua dimulai sejak calon suami atau istri memilih pasangan hidupnya. Pada saat yang sama, syariat Islam menempatkan pemeliharaan terhadap keturunan (bifz: annas) termasuk salah satu dari lima tujuan utama (ad-dharuriyat alkhamsah) syariat Islam. ${ }^{6}$

Karena begitu esensialnya posisi anak dalam keseluruhan batang tubuh agama Islam, hak-hak anak mencakup semua aspek yang memungkinnya tumbuh dengan sebaik-baiknya untuk pada waktunya nanti dapat melanjutkan peran kekhalifahan para pendahulunya dan menjadi pewaris yang baik untuk memakmurkan bumi manusia dalam keseluruhan aspeknya. Oleh karena itu Islam menetapkan hak-hak dasar bagi anak meliputi, diantaranya: hak mendapatkan perlindungan dari segala kekerasan,

${ }^{5}$ Imam Abu Hamid Muhammad bin Muhammad al-Gazali, Ibya Ulum adDin, (Beirut: Dar al-Fikr, 1995), juz 2 h. 28.

${ }^{6}$ Erma Suriani, op.cit, h. 75 


\section{Ijtimaiyya: Jurnal Pengembangan Masyarakat Islam 10 (2) (2017)}

hak perwalian, hak memiliki nasab, hak mendapat susuan, hak pendidikan dan hak perawatan (Hadhānah).

Penjaminan terwujudnya hak-hak ini, bukan sekedar menjadi urusan orang tua, tetapi juga masyarakat dan Negara. Oleh karena itulah, PBB mendeklarasikan Konvensi Hak-Hak Anak yang disetujui oleh Majelis Umum Perserikatan Bangsa-bangsa pada tanggal 20 Nopember 1989 dan telah diratifikasi Indonesia pada tahun 1990. Konvensi ini telah didahului oleh berbagai deklarasi tingkat PBB tentang hak-hak anak, diantaranya, Deklarasi Jenewa Tahun 1979 yang merupakan cikal bakal dari lahirnya Konvensi Hak-hak Anak PBB Tahun 1989. Di bagian I, pasal 7 dari deklarasi ini disebutkan secara ringkas dan tegas tentang hak-hak anak, bahwa: "sejak lahir setiap anak berhak atas perlindungan, pendidikan dan pemeliharaan baik secara material, keilmuan dan kultural yang wajib diberikan oleh orang tua, masyarakat dan Negara. Perhatian khusus juga wajib diberikan kepada janin dan ibu yang mengandungnya".

Dalam UUPA No. 23 Tahun 2002, Bab III Pasal 4 sampai dengan pasal 18, disebutkan hak-hak anak sebagai berikut:

1. Hak hidup, tumbuh dan berkembang

2. Hak memiliki nama sebagai identitas kewarganegaraan

3. Hak beragama dan berekspresi

4. Hak diasuh dan dibesarkan oleh orang tua sendiri

5. Hak kesehatan

6. Hak pendidikan

7. Hak didengar

8. Hak bermain

9. Hak mendapatkan perlindungan

Kebutuhan-kebutuhan dasar anak untuk tumbuh kembang yang optimal meliputi Asuh, Asih, dan Asah. Penjabarannya adalah sebagai berikut:

1. Kebutuhan fisik-biologis (asuh): Meliputi kebutuhan sandang, pangan, papan seperti: nutrisi, imunisasi, kebersihan tubuh dan lingkungan, pakaian, pelayanan

${ }^{7}$ Ibid, h. 75-76 dan lih. Mushthafa az-Zuhaili, Huquq al-Aulaq 'ala alWalidain fi as-Syari'ah al-Islamiyah, tt. 
kesehatan dan pengobatan, olahraga, bermain dan beristirahat.

2. Kebutuhan kasih sayang dan emosi (asih): Pada tahun-tahun pertama kehidupannya (bahkan sejak dalam kandungan), anak mutlak memerlukan ikatan yang erat, serasi dan selaras dengan ibunya untuk menjamin tumbuh kembang fisikmental dan psikososialnya.

3. Kebutuhan Stimulasi (asah). Anak perlu distimulasi sejak dini untuk mengembangkan sedini

mungkin kemampuan sensorik, motorik, emosi-sosial, bicara, kognitif, kemandirian, kreativitas, kepemimpinan, moral dan spiritual anak.

\section{Macam-Macam Hadhānah}

Pembicaraan tentang Hadhänah lebih pada persoalan Hadhānah atau pemeliharaan anak ketika orang tua mereka berpisah atau bercerai. Karena biasanya persoalan pengasuhan anak itu akan menjadi perselisihan ketika kedua orang tua bercerai. Adapun ketika rumah tangga mereka utuh, maka persoalan ini relatif tidak mengemuka ke permukaan. Ayah dan ibu akan berbagi tugas pengasuhan anak dalam kehidupan rumah tangga mereka.

Dalam Kompilasi Hukum Islam misalnya, pembahasan Hadhānah ini sangat terkait dengan kasus atau masalah perceraian. Setidaknya ada dua pasal yang menentukan pengasuhan anak yaitu Pasal 105 dan Pasal 156. Pasal 105 menentukan tentang pengasuhan anak pada dua keadaan. Pertama, ketika anak masih dalam keadaan belum mumayiz, (kurang dari 12 tahun) pengasuhan anak ditetapkan kepada ibunya. Kedua ketika anak tersebut mumayiz. (usia 12 tahun ke atas) dapat diberikan hak kepada anak untuk memilih diasuh oleh ayah atau ibunya. Adapun Pasal 156 mengatur tentang pengasuhan anak ketika ibu kandungnya meninggal dunia dengan memberikan urutan yang berhak mengasuh anak.

Dalam kaitan dengan bolehkah ditanyakan atas pilihan anak akan ikut ibu atau ayahnya yang bercerai yang usia anak tersebut belum berusia 12 tahun sebagaimana yang diatur dalam pasal 105 huruf (a) Kompilasi Hukum Islam bahwa: pemeliharaan anak yang belum mumayiz/belum berumur 12 tahun adalah hak ibunya. Dapat ditafsirkan bahwa kategori anak belum mumayiz, adalah di bawah 


\section{Ijtimaiyya: Jurnal Pengembangan Masyarakat Islam 10 (2) (2017)}

umur 12 tahun. Sedangkan dalam literatur-literatur lain arti dari mumayiz, adalah anak yang belum bisa membedakan antara mana yang bermanfaat dan mana yang membahayakan dirinya.

Hal ini sesuai dengan aturan Pasal 10 Undang-Undang No. 23 Tahun 2003 tentang Perlindungan anak bahwa: (1) Setiap anak berhak untuk tidak dipisah: Setiap anak berhak mengatakan dan didengar pendapatnya, menerima dan memberikan informasi sesuai dengan tingkat kecerdasan dan usianya demi pengembangan dirinya sesuai dengan nilai-nilai kesusilaan dan kepatutan.

Begitupun bila telah memilihnya itu tetap harus diberikan hak kepada ayahnya untuk diberikan akses melihat, menjenguk, mengajak jalan-jalan dan hak yang sama untuk bermusyawarah dalam menentukan pendidikan anak tersebut.

Berdasarkan penjelasan di atas, maka Hadhānah itu terbagi:

1. Hadhānah Pada Masa Perkawinan.

Berdasarkan Undang-Undang Pernikahan No. 1 tahun 1974 pasal 45, 465, 47 menyebutkan bahwa: Pasal 45:

a. Kedua orang tua wajib memelihara dan mendidik anak mereka sebaikbaiknya.

b. Kewajiban orang tua yang dimaksud dalam ayat 1 pasal ini berlaku sampai anak itu kawin atau berdiri sendiri berlaku terus meski perkawinan antara orang tua putus.

Pasal 46:

a. Anak wajib menghormati orang tua dan menaati kehendak mereka dengan baik.

b. Jika anak telah dewasa, ia wajib memelihara menurut kemampuannya, orang tua dan keluarga dalam garis lurus ke atas, bila mereka memerlukan batuannya.

Pasal 47:

a. Anak yang belum mencapai umur 18 tahun atau belum pernah melangsungkan perkawinan ada di bawah kekuasaan orang tuanya, selama mereka tidak dicabut dari kekuasaanya.

b. Orang tua mewakili anak tersebut mengenai perbuatan hukum di dalam dan di luar pengadilan.

Berdasarkan pada ayat 1 Pasal 47, 49 menyebutkan bahwa kekuasaan salah satu atau kedua orang tuanya dicabut dari anaknya atas permintaan orang tua lain, keluarga anak dalam garis lurus ke atas dan saudara kandung yang telah 
dewasa atau pejabat yang berwenang dengan keputusan pengadilan meskipun dicabut mereka tetap berkewajiban. Namun demikian, orang tua masih memiliki kewajiban atas biaya pemeliharaan anak tersebut (ayat 2) berkaitan dengan pemeliharaan anak juga, orang tua pun mempunyai tanggung jawab yang berkaitan dengan kebendaan.

Berdasarkan pasal $106 \mathrm{KHI}$ disebutkan bahwa orang tua berkewajiban merawat dan mengembangkan harta anaknya yang belum dewasa atau di bawah pengampuan. Dan orang tua bertanggung jawab atas kerugian yang ditimbulkan karena kesalahan dan kelalaian dari kewajiban.

Ditambah dengan KHI pasal 98 dan 99 tentang pemeliharaan anak: Pasal 98 :

1. Batas usia anak yang mampu berdiri sendiri atau dewasa 21, sepanjang tidak cacat fisik atau mental.

2. Orang tuanya mewakili anaknya tersebut mengenai segala perbuatan.

3. PA (Pengadilan Agama) dapat menunjuk kerabat terdekat yang mampu bila orangtuanya tidak mampu.

Pasal 99 : Anak yang sah adalah :

1. Anak yang dilahirkan dalam atau akibat perkawinan yang sah;

2. Hasil dari perbuatan suami istri yang sah di luar rahim dan dilahirkan oleh istri tersebut;

\section{Hadhānah Pada Masa Perceraian}

Timbulnya perceraian antara suami istri bukanlah halangan bagi anak untuk memperoleh hak pengasuhan atas dirinya dari kedua orang tuanya, sebagaimana yang telah diatur pada Undang -Undang Pernikahan No.1 tahun 1974 Pasal 41 tentang akibat putusnya perkawinan karena perceraian adalah:

a. Baik ibu atau bapak tetap berkewajiban memelihara, mendidik anak-anaknya, semata-mata berdasarkan kepentingan anak bilaman ada perselisihan mengenai pengasuhan anak bilamana ada perselisihan mengenai pengasuhan anak-anak, pengadilan memberi keputusan;

b. Bapak yang bertanggung jawab atas semua biaya pendidikan dan pemeliharaan, bilamana bapak dalam 
kenyataannya tidak dapt memenuhi kewajiban tersebut, pengadilan dapat menentukan bahwa ibu ikut memikul biaya tersebut.

c. Pengadilan dapat mewajibkan kepada bekas suami untuk memberikan biaya penghidupan dan menentukan suatu kewajiban bagi bekas istri.

Kompilasi Hukum Islam pada pasal 105 kemudian mengatur lebih rinci mengenai permasalahan perceraian dan kondisi anak pada saat itu belum mumayyiz yaitu:

a. Belum berumur 12 tahun masih haknya seorang ibu.

b. Ketika sudah mumayyiz disrahkan kepada anaknya untuk memilih diantara kedua orang tuanya sebagai pemegang hak pemeliharaannya.

c. Biaya pemeliharaan di tanggung oleh ayah. bahwa:

Sedangkan menurut fikih 5 Madzab, menyatakan

a. Imam Hanafi menyatakan bahwa anak yang berusia 7 tahun untuk laki- laki dan 9 tahun untuk perempuan.

b. Imam Maliki menyakan bahwa Anak laki- laki hingga baligh dan perempuan hingga menikah.

c. Imam Syafi'i menyatakan bahwa Tidak ada batasan tetap tinggal bersama ibunya sampai ia bisa menentukan atau berfikir hal yang terbaik baginya. Namun bila ingin bersama ayah dan ibunya, maka dilakukan undian, bila si anak diam berarti memilih ibunya.

d. Imam Hambali menyatakan bahwa Masa anak laki- laki dan perempuan dan sesudah itu disuruh memilih ayah atau ibunya.

e. Imamiyyah: Masa asuh anak untuk laki- laki 2 tahun, sedangkan anak perempuan 7 tahun. Sesudah itu haknya ayah, hingga mencapai 9 tahun bila dia perempuan dan 15 tahun bila dia laki-laki, untuk kemudian disuruh memilih dia siapa yang ia pilih.

Sedangkan dalam KHI pada pasal 156 juga mengatur tentang Hadhānah pada perceraian:

a. Anak yang belum mumayyiz dipelihara oleh ibunya kecuali telah meninggal dunia, maka kedudukannya diganti oleh; 
1) Wanita-wanita dalam garis lurus ke atas dari ibu,

2) Ayah,

3) Wanita dalam garis lurus ke atas dari ayah,

4) Saudara-saudara perempuan dari anak yang bersangkutan,

5) Wanita-wanita kerabat sedarah menurut garis samping dari ibu,

6) Wanita-wanita sedarah menurut garis samping ayah.

b. Anak yang sudah mumayyiz berhak memilih untuk mendapatkan Hadhānah dari ayahnya atau ibunya.

c. Apabila pemegang Hadhānah tidak dapat menjamin keselamatan jasmani dan rohani anak meskipun tercukupi biayanya, maka atas permintaan kerabat yang juga mempunyai hak yang dapat menuntut ke pengadilan untuk memindahkan hak Hadhānah.

d. Biaya Hadhānah tangung jawab ayah sekurangkurangnya sampai dewasa dan dapat mengurus sendiri (21 tahun).

e. Apabila ada perselisihan Pengadilan Agama dapat memutuskan berdasarkan a, b, c dan d.

f. Pengadilan dapat pula mengingat kemampuan ayahnya pada penetapan jumlah biaya untuk memelihara dan pendidikan anak.

Syarat orang yang berhak memegang hak pemeliharaan anak/Hadhanah adalah sebagai berikut:

1. Baligh dan tidak terganggu ingatannya.

2. Mempunyai kemauan dan kemampuan untuk memelihara dan mendidik mabdhum (anak yang diasuh) dan tidak terikat dengan suatu pekerjaan yang dapat mengakibatkan tugas Hadhānah menjadi terlantar.

3. Jika pemegang Hadhānah itu ibu disyaratkan tidak kawin dengan laki-laki lain.

4. Beragama Islam.

\section{Biaya Hadhānah}

Terkait dengan biaya Hadhānah dapat dijelaskna bahwa, Ibu tidak berhak atas upah Hadhānah dan menyusui, selama ia masih menjadi istri dari ayah anak itu, atau selama masih dalam iddah. Karena dalam keadaan tersebut ia masih mempunyai nafkah 


\section{Ijtimaiyya: Jurnal Pengembangan Masyarakat Islam 10 (2) (2017)}

sebagai istri atau nafkah masa iddah. Adapun sesudah habis masa iddanya maka ia berhak atas upah itu seperti haknya kepada upah menyusui. Seorang ayah wajib membayar upah penyusuan dan Hadhānah. Ia juga wajib membayar ongkos sewa rumah atau perlengkapannya sekiranya ibu tidak memiliki rumah sendiri sebagai pengasuh anak kecilnya. Ia juga wajib membayar gaji pembantu rumah tangga atau menyediakan pembantu tersebut jika si ibu membutuhkannya dan ayah memiliki kemampuan untuk itu. Hal ini bukan termasuk dalam bagian nafkah khusus bagi anak kecil' seperti: makan, minum, tempat tidur. Obat-obatan dan keperluan pokok lain yang sangat diburuhkannyu. Tetapi, upah ini hanya wajib dikeluarkannya saat ibu pengasuh mengasuh asuhannya. Dan upah ini menjadi utang yang ditanggung oleh ayah serta baru bisa dilepas dari tanggungan ini kalau dilunasi atau dibebaskan.

Di dalam Kompilasi Hukum Islam (KHI) pasal 80 ayat (4) diperinci nafkah yang menjadi kewajiban suami terhadap anak istrinya, yaitu meliput: Nafkah, kiswah (pakaian) dan tempat kediaman bagi istri; Biaya rumah tangga, biaya perawatan dan biaya pengobatan bagi istri dan anak; dan biaya pendidikan bagi anak. Jadi nafkah itu dalam arti luas tidak hanya makanan, pakaian dan tempat tinggal, tetapi juga biaya pengobatan, pendidikan dan bahkan pembantu rumah tangga yang diperlukan dalam suatu keluarga, dengan melihat kepada kemampuan suami.

Kewajiban ini juga diatur dalam pasal 41 butir b dan c Undang-Undang Nomor 1 tahun 1974 tentang Perkawinan; Putusnya perkawinan karena perceraian bapak yang bertanggung jawab atas semua biaya pemeliharaan dan pendidikan yang diperlukan anak. Bilamana bapak dalam kenyataan tidak dapat memenuhi kewajiban tersebut, pengadilan dapat menentukan bahwa ibu ikut memikul biaya tersebut.

Di dalam Kompilasi Hukum Islam pasal 156 dinyatakan "semua biaya Hadhānah dan nafkah anak menjadi tanggungan ayah menurut kemampuannya, sekurang-kurangnya sampai anak itu dewasa dan dapat mengurus diri sendiri (21 tahun). Untuk bisa mengemban tugas Hadhānah disyaratkan: Baligh dan berakal; Mampu mendidik anak; Terpercaya dan berbudi luhur; Islam, 
orang kafir tidak boleh melaksanakan tugas Hadhānah anak muslim; Tidak bersuami (belum menikah lagi). ${ }^{8}$

\section{Panti Asuhan}

Panti asuhan adalah unsur pelaksana dinas sosial di bidang rehabilitasi dan pelayanan sosial terhadap anak-anak ${ }^{9}$ yatim piatu, dan anak-anak terlantar. Panti itu sendiri dipimpin oleh seorang pimpinan panti yang bertanggung jawab kepada dinas. Panti asuhan merupakan suatu lembaga usaha kesejahteraan sosial yang mempunyai tanggungjawab untuk memberikan pelayanan kesejahteraan sosial kepada anak-anak terlantar serta melaksanakan pelayanan pengganti, atau perwakilan anak dalam memenuhi kebutuhan fisik, mental, dan sosial kepada anak asuh sehingga memperoleh kesempatan yang luas, tepat dan memadai bagi perkembangan kepribadiannya sesuai dengan yang di harapakan sebagai bagian dari generasi penerus cita-cita bangsa, sebagai insan yang akan turut serta aktif di dalam bidang pembangunan nasional.

Panti asuhan diartikan sebagai suatu lembaga untuk mengasuh anak-anak, menjaga dan memberikan bimbingan dari pimpinan kepada anak dengan tujuan agar mereka menjadi manusia dewasa yang cakap dan berguna serta bertanggung jawab atas dirinya, dan terhadap masyarakat di kemudian hari. Panti asuhan dapat pula diartikan atau berfungsi sebagai pengganti keluarga, dan pimpinan panti asuhan sebagai pengganti orang tua, sehubungan dengan orang tua anak tidak dapat berfungsi

8 Nurwahidah, Kejahatan Terhadap Anak Dan Solusinya Menurut Hukum Islam, Syariah Jurnal Ilmu Hukum, Volume 15, Nomor 2, Desember 2015,h. 136

${ }_{9}$ Pengeritan anak yang digunakan oleh Pengadilan Agama, terdapat pada Undang-undang No. 1 Tahun 1974 Tentang Perkawinan, Bab IX Tentang Kedudukan Anak, Pasal 42 yaitu: anak yang sah adalah anak yang dilahirka dalam atau sebagai akibat perkawinan yang sah. Pengertian yang sama juga terdapat dalam KompilasiHukum Islam (KHI) Pasal 99 huruf a dan b yang berbunyi: anak yang sah adalah: (a) anak yang dilahirkan dalam atau akibat perkawinan yang sah, (b) hasil perbuatan suami isteri yang sah di luar rahim dan dilahirkan oleh isteri tersebut. Sumber pengertian anak yang kedua bersumber dari Perundang-undangan umum, yaitu Undang-undang No. 23 Tahun 2002 Tentang Perlindungan Anak. Dalam undang-undang tersebut, pengertian anak terdapat pada Pasal 1 ayat (1) yang berbunyi: "Anak adalah seorang yang belum berusia 18 (delapan belas) tahun, termasuk anak yang masih dalam kandungan.” 
sebagaimana mestinya dalam mendidik dan mengasuh anaknya. Panti asuhan baik yang diselenggarakan oleh Negara maupun yayasan dimaksudkan sebagai tempat bernaung bagi anak-anak terlantar dalam pertumbuhan perkembangannya mengalami berbagai macam gangguan sosial, baik yang bersifat intrinsik, yaitu berasal dari anak itu sendiri, seperti cacat mental atau fisik. Gangguan sosial yang bersifat ekstrinsik, yaitu karena pengaruh lingkungan di luar diri anak, seperti orang tua meninggal dunia, perpecahan dalam keluarga, kemiskinan dan lain-lain sehingga anak menjadi terlantar.

Salah satu kebutuhan penting manusia selain sandang, pangan, papan, kesehatan adalah kebutuhan akan pendidikan. Kebutuhan akan pendidikan ini sangat penting bagi setiap manusia, maka pemerintah telah menuangkan dalam Garis-garis Besar Haluan Negara (GBHN) Tap MPR No. IV/MPR/1973 tentang tujuan pendidikan.

Berdasarkan Konvensi Hak-Hak Anak yang disetujui oleh Majelis Umum Perserikatan Bangsa-bangsa pada tanggal 20 Nopember 1989 dan telah diratifikasi Indonesia pada tahun 1990, Bagian 1 Pasal 1, yang dimaksud Anak adalah setiap orang yang berusia dibawah 18 tahun, kecuali berdasarkan undang-undang yang berlaku bagi anak ditentukan bahwa usia dewasa dicapai lebih awal. Berdasarkan Undang-undang No. 23 tahun 2002 tentang Perlindungan Anak (UUPA), pasal 1 ayat 1, Anak adalah seseorang yang belum berusia 18 (delapan belas) tahun, termasuk anak yang masih dalam kandungan.

Ada 4 prinsip dasar hak anak yang terkandung di dalam Konvensi Hak-hak Anak yang disetujui oleh Majelis Umum Perserikatan Bangsabangsa pada tanggal 20 Nopember 1989 dan telah diratifikasi Indonesia pada tahun 1990, yaitu: nondiskriminasi, kepentingan yang terbaik bagi anak, hak untuk hidup, kelangsungan hidup dan perkembangan, serta penghargaan terhadap pendapat anak.

\section{Pendirian Panti Asuhan Budi Mulya}

Banyak faktor yang melatarbelakangi pendirian Muhammadiyah. Salah satunya adalah Muhammadiyah merupakan organisasi yang mementingkan kehidupan masyarakat, antara lain 
dengan membangun rumah sakit, mendirikan panti asuhan, menyantuni fakir miskin, mendirikan sekolah dari taman kanakkanak sampai perguruan tinggi. Bidang pendidikan dianggap perlu dan penting dilaksanakan guna menunjang sumber daya manusia yang mampu menjawab tantangan masa depan.

Bidang pendidikan dianggap penting sebagai usaha untuk mencerdaskan kehidupan bangsa, di bidang kewanitaan, kepemudaan, kemahasiswaan, di dunia pelajar, dan di dunia kesehatan. Santunan sosial dan kesejahteraan serta penyiaran Islam merupakan dakwah yang harus terus ditingkatkan sesuai dengan perkembangan dan tuntutan jaman.

Jika hal tersebut kita renungkan, maka akan tampak sekali sungguh besar jasa Muhammadiyah dalam gerakan mencerdaskan bangsa. ${ }^{10}$ Pada jaman penjajahan Belanda, Muhammadiyah sangat aktif dalam menjalankan gerakan pembaharuan (tajdid) di tengahtengah masyarakat. Muhammadiyah mengadopsi teknik barat dalam bidang pendidikan, dan menjadikannya sebagai media untuk melawan pemerintah secara kultural. Sikap menentang pemerintah kolonial yang diwujudkan melalui cara-cara yang baik, hal itu menyebabkan gagasan penentangan Muhammadiyah tidak beralasan untuk ditindak oleh Belanda, sampai akhirnya menang.

Pada jaman Jepang, para tokoh Muhammadiyah tetap dapat melestarikan kepribadian Muhammadiyah, kepribadian Muhammdiyah adalah ciri-ciri dan sifat-sifat khas Muhammadiyah yang merupakan perwujudan jiwa dan semangat Muhammadiyah yang memberi warna setiap gerak langkah perjuangan dan harus dimiliki dan dipelihara oleh setiap warga Muhammadiyah.

Pada jaman kemerdekaan, Muhammadiyah turut mempunyai pesan besar dalam pembangunan di bidang keagamaan, pendidikan, ekonomi dan sosial. Banyak amal usaha yang dimiliki oleh Persyarikatan Muhammadiyah antara lain Universitas Muhammadiyah, sekolah-sekolah Muhammdiyah dan Rumah Sakit Muhammadiyah. Namun hal ini barulah pada awal perjuangan Muhammadiyah untuk melanjutkan cita-cita pendiri Muhammadiyah (K. H. Ahmad Dahlan) yang masih panjang. ${ }^{11}$

${ }^{10}$ Yuni, op.cit, h. 185-186

${ }^{11}$ Ibid, h. 186 


\section{Ijtimaiyya: Jurnal Pengembangan Masyarakat Islam 10 (2) (2017)}

Semenjak majlis PKU dibentuk pertama kali pada tahun 1915 dengan nama Penolong Kesengsaraan Oemoem (PKO), maka segala tugas pengelolaan lembaga-lembaga sosial Muhammadiyah berada di bawah naungan majlis tersebut, termasuk yang tercakup di dalamnya adalah penampungan dan penyantunan terhadap anak yatim dan terlantar. PKO tersebut pada pertama kalinya merealisasikan ide dengan mendirikan rumah yatim piatu di Yogyakarta pada tahun 1922, yang dipimpin oleh Dokter Somawidagdo ${ }^{12}$ Selanjutnya pendirian rumah sakit tersebut tidak hanya di Yogayakarta saja, melainkan juga berkembang di kota-kota yang lainnya bersama dengan berkembangnya Muhammadiyah diluar Yogyakarta.

Geliat kegiatan pendirian panti asuhan di propinsi Lampung diawali dengan pendirian panti asuhan Budi Utomo Muhammadiyah Metro. Ia merupakan panti asuhan tertua di propinsi Lampung. Dirintis pendiriannya oleh beberapa orang kaum muslimin yang peduli dengan kondisi sosial masyarakat pada saat itu. Mereka para pendiri panti asuhan tersebut aktif di Masyumi. Karena kesibukan partai, mereka bekerja sama dalam pengelolaan panti dengan Muhammadiyah. Dan akhirnya mereka menyerahkan pengelolaan panti asuhan Budi Utomo kepada Muhammadiyah tahun 1952. Panti Asuhan tersebut terus berkiprah sampai dengan sekarang.

Panti asuhan Budi Mulya awalnya dibangun secara pribadi oleh warga Muhammadiyah. Mereka antara lain : Mulyanzen dan H. Burda'i Pulun. Kemudian dibantu oleh H.M Hasyim Abdullah, H. Abdul Karim dan Toyib, serta donator lainnya. Pimpinan wilayah Muhammadiyah provinsi Lampung pada waktu itu mendukung dan membantu mencarikan dana dari luar negeri; dalam hal ini donator dari Kuwaait. Dana yang dihasilkan digunakan untuk membangun asrama putri dan bangunan sekolah berupa madrasah Tsanawiyah dua lantai. Pembangunan di mulai tahun 1987 dan mulai menerima anak asuh mulai tahun $1988 .{ }^{13}$

${ }^{12}$ Deliar Noor, Gerakan Modern Islam di Indonesia 1900-1942, Jakarta : LPE3S, 1980), h. 90.

${ }^{13}$ Statuta Panti Asuhan Budi Mulya Muhammadiyah Sukarame tahun 2007 pasal 2 
Nama awal panti asuhan ini adalah Panti Asuhan Keluarga Budi Mulya. Dalam perjalanannya nama Budi Mulya ini juga digunakan oleh salah satu lembaga pendidikan Kristendi kota Bandar Lampung. Lalu berdasarkan kesepakatan pendiri dan pengurus wilayah Muhammadiyah waktu penyerahan panti asuhan ini kepada persyarikatan Muhammadiyah, namanya dirubah menjadi Panti Asuhan Yatim Piatu Budi Mulya Muhammadiyah. Tahun 1991 panti asuhan Panti Asuhan Yatim Piatu Budi Mulya Muhammadiyah diberi hak untuk menjalankan dan menyelenggarakan pendidikan Islam dengan kurikulum diniyah atau pondok pesantren dengan nama pondok pesantren Darul Arqom Muhammadiyah. Pondok ini berdiri berdasarkan izin kepala kantor wilayah Departemen Agama provinsi Lampung tanggal 13 Desember 1991 dan terdaftar pada Majelis Pendidikan Dasar Dan Menengah Pimpinan Pusat Muhammadiyah dengan piagam pendirian tanggal 7 Desember 1991. Sejak tahun 1992, panti asuhan Budi Mulya telah diakui keberadaannya sebagai organisasi sosial persyarikatan Muhammadiyah dan pada tahun 2003 oleh dinas kesejahteraan sosial provinsi Lampung. ${ }^{14}$

a. Visi dan Misi Panti Asuhan Budi Mulya

Visi Panti Asuhan Yatim Piatu Budi Mulya Muhammadiyah adalah membangun kader umat yang bertakwa dan mandiri. Sedangkan misinya adalah:

1. Memberikan pendidikan dan ketrampilan kepada seluruh anak asuh dengan pola pdendidikan pondok pesantren

2. Membentuk anak asuh sebagai kader umat/ Muhammadiyah yang mempunyai etika, bermoral dan bertakwa

3. Membentuk anak asuh agar berwiraswasta dan produktif

4. Meningkatkan manajemen penyelenggaran panti

5. Mempersiapkan sarana dan prasarana untuk menunjang program kegiatan panti

6. Membina hubungan dengn seluruh stake holder yang mendukung pengembangan panti. ${ }^{15}$

\footnotetext{
${ }^{14}$ Ibid

${ }^{15}$ Ibid pasal 3
} 


\section{Ijtimaiyya: Jurnal Pengembangan Masyarakat Islam 10 (2) (2017)}

Untuk mewujudkan visi dan misi di atas terangkum dalam berbagai program-programberikut ini: (1) menyiapkan kurikulum pendidikan Al-Islam Kemuhammadiyahan, bahasa Inggris, bahasa Arab dan ketrampilan, (2) menyiapkan tenaga pengajar/ pendidikan yang berkualitas, (3) menyiapkan sarana dan prasarana yang memadai, mengikutsertakan pengasuh dalam kegiatan keorganisasian, IPM dan tapak suci, (4) mengikutsertakan anak asuh dalam pengajian oleh PCM/ Aisyiyah,(8) meningkatkan kedisiplinan anak asuh dalam/ semua kegiatan, (9) memberikan sanksi kepada anak asuh yang tidak disiplin, (10) memberikan reward kepada anak asuh yang berprestasi, (11) meningkatkan pelaksaaan tahfidz Al-Qur'an dan Muhadharah, dan (12) mengadakan pelaksanaan koperasi UEP (Usaha Ekonomi Produktif).

b. Program Pengasuhan Anak di Panti Asuhan Budi Mulya Syarat penerimaan anak asuh dengan ketentuan sebagai berikut:

1. Anak yatim, piatu yang berasal dari keluarga duafa

2. Pendidikan minimal sudah lulus sd atan sekurangkurangnya kelas $6 \mathrm{SD}$

3. Sehat jasmani dan rohani ${ }^{16}$

Mereka harus menyiapkan kelengkapan administrasi penerimaan:

1. Surat permohonan keluarga atau wali calon anak asuh mengajukan permohonan kepada ketua panti asuhan dengan kelengkapan surat surat sebagai berikut

2. Surat keterangan dari pamong setempt yang menjelaskan tentang status calon anak asuh

3. Surat keterangan kelahiran

4. Surat keterangan sehat

5. Surat keterangan kepala sekolah/ surat pindah dari sekolah asal Calon anak asuh

6. Rekoendasi dari pimpinan muhmmadiyah setempat

7. Surat pernyataan dari wali/ keluarga calon anak asuh untuk menyerahkan pengasuhan kepada panti asuhan ${ }^{17}$ 
Langkah berikutnya adalah survey lokasi, yakni:

1. Setelah persyaratan lengkap, pengurus menugaskan pengasuh untuk melakuakan survey ke tempat calon anak asuh untuk mengetahui kebenaran data-datanya

2. Menyampaikan laporannnya kepada pengurus.

Barulah kemudian penerimaan anak asuh secara:

1. Setelah memenuhi persyaratan tersebut di atas, pengurus dapat memutuskan menerima calon anak asuh dengan masa percobaan selama 3(tiga) bulan

2. Apabila selama masa percobaan anak asuh tersebut memenuhi persyaratan dan tidak ada masalah akan dapat diterima sebagai anak asuh tetap. ${ }^{18}$

Anak asuh yang dibina di panti asuhan Budi Mulya adalah anak yatim dan atau piatu, serta dhuafa yang berasal dari seantero propinsi Lampung. Anak asuh tersebut telah mendapatkan rekomendasi dari Pengurus Cabang Muhammadiyah tempat asalnya dan telah lulus seleksi untuk menjadi anak asuh dip anti asuhan Budi Mulya. ${ }^{19}$

Anak-anak asuh tersebut terdiri dari anak laki-laki dan perempuan. Jumlah mereka 120 (seratus dua puluh) orang. Tujuh puluh orang duduk di madrasah Tsanawiyah, lima puluh orang di madrasah Aliyah, dan satu orang di Madrasah Ibtidaiyah. Mereka tinggal di gedung yang terpisah dalam satu kompleks Madrasah Tsanawiyah, Madrasah Aliyah, dan Panti Asuhan Budi Mulya. Kompleks ini terletak di jalan P. Sangiang kelurahan Sukarame kecamatan Sukarame Bandar Lampung.

Anak-anak asuh tersebut terdiri dari usia sekolah dasar, sekolah menengah pertama, dan sekolah menengah atas. Mereka bersekolah di Madrasah Ibtidaiyah Terpadu (MIT) Muhammadiyah Sukarame, Madrasah Tsanawiyah Muhammadiyah Sukarame, dan Madrasah Aliyah Muhammadiyah Sukarame. Tsanawiyah Muhammadiyah Sukarame dan Madrasah Aliyah Muhammadiyah Sukarame terletak satu kompleks dengan panti asuhan Budi Mulya.

\footnotetext{
${ }^{18}$ Ibid

${ }^{19}$ Beni Setiawan, Pengasuh Panti Asuhan Budi Mulya, Wawancara, tanggal 2 Juni 2015
} 


\section{Ijtimaiyya: Jurnal Pengembangan Masyarakat Islam 10 (2) (2017)}

Adapun MITM Sukarame berjarak seratus meter dari kompleks panti asuhan. Secara sederhana dapat dijelaskan bahwa kegiatan anak asuh panti asuhan Budi Mulya pada jam sekolah pukul 07.00 s/d 14.00 dipusatkan di sekolah. Dan selebihnya terpusat di kompleks panti asuhan. Berikut ini akan disajikan jadwal kegiatan anak asuh panti asuhan Budi Mulya Sukarame.

Setiap harinya anak-anak asuh panti asuhan Budi Mulya bangun jam 03.30 wib pagi. Mereka mengawali harinya dengan melaksanakan salat Tahajud. Salat Tahajud ini dilaksanakan secara berjamaah di masjid. Salat Tahajud ini diimami oleh anak asuh senior ataupun pengasuh. Dalam kenyataannya terdapat anak asuh yang tidak bangun untuk salat Tahajud. Namun mereka harus bangun untuk melaksanakan salat Subuh berjamaah di masjid. Salat tahajud berjamaah ini diwajibkan pada hari Jumat dan Sabtu. Adapun pada hari-hari lainnya bersifat anjuran. ${ }^{20}$

Salat Tahajud dilanjutkan dengan berzikir dan doa sambil menunggu datanga waktu salat Subuh. Setelah masuk waktu salat Subuh, maka salat Subuh dilaksanakan secara berjamaah. Setelah salat Subuh diisi dengan kegiatan-kegiatan:

1. Selasa dan Rabu dengan kegiatan Muhadarah/ Ta'lim dengan beragam pembahasan seperti bahasa Arab, Hadis, Fiqh, Tafsir, Akidah Islamiah, dan lainnya.

2. Senin diisi dengan membaca al-Qur'an atau tadarus

3. Kamis, Jumat, dan Sabtu dilaksanakan kegiatan Tahfizh alQur'an.

4. Minggu diisi dengan kegatan olah raga seperti senam atau lari pagi.

Kemudian aktivitas dilanjutkan dengan gotong royong bersih-bersih kompleks dan persiapan untuk berangkat sekolah dan sarapan pagi. Dan pada pukul tujuh dilaksanakan apel pagi. Apel pagi ini harus diikuti seluruh anak asuh. Apel pagi ini untuk memastikn kesiapan para anak asuh sebelum berangkat ke Madrasah masing-masing.

Selanjutnya pukul tujuh sampai pukul tiga belas siang, para anak asuh berada di madrasahnya masing-masing. Walaupun

20 Beni Setiawan, Pengasuh Panti Asuhan Budi Mulya, Wawancara, tanggal 2 Juni 2015 
berada dalam satu kompleks ataupun tidak jauh dari kompleks panti asuhan, namun secara tanggung jawab pengawasan, para anak asuh berada dalam pengawasan guru-guru mereka di madrasah mereka masing-masing. ${ }^{21}$ Namun setelah salat Zuhur, mereka pulang kembali ke panti asuhan untuk makan siang.

Pukul lima belas, mereka bersiap-siap berangkat ke masjid untuk salat Asar. Setelah salat Asar, mereka biasanya menghafalkan beberapa Mufradat bahasa Arab atau beberapa vocabulary bahasa Inggris. Setelah itu mereka piket bersih-bersih halaman kompleks, lalu beristirahat ataupun sekedar bermain-main selama tidak keluar di area kompleks. Jika terdapat keperluan yang mengharuskan mereka keluar kompleks harus mendapatkan izin dari pengurus panti.

Pukul tujuh belas tiga puluh menit, bersiap-siap untuk ke masjid untuk melaksanakan salat Maghrib berjamaah. Setelah melaksanakan salat Maghrib, biasanya diisi dengan membaca alQur'an atau mengaji bersama-sama. Lalu makan malam bersama dan persiapan untuk salat Isya ke masjid. Untuk melaksanakan salat Isya ini, mereka harus membawa serta buku-buku pelajaran madrasah mereka. Karena setelah salat Isya akan dilanjutkan dengan belajar pelajaran madrasah mereka masing-masing. Kecuali pada malam Selasa dan Jumat, sehabis pelaksanaan salat Isya dilanjutkan dengan acara Muhadarah dalam berbagai brahasa, yakni bahasa Indonesia, Arab, dan Inggeris. ${ }^{22}$

Di samping kebutuhan rohani berupa pendidikan formal dan pengetahuan agama mereka, pihak panti juga mengupayakan pemenuhan kebutuhan jasmani para anak asuh panti asuhan Budi Mulya. Sebagaimana telh disinggung sebelumnya, mereka para anak asuh makan tiga kali sehari, yakni saraapan di pagi hari sebelum berangkat ke madrasah, makan siang, dan makan malam. Menu makanan yang disajikan memang belum tertata secara terjadwal dalam sebuah jadwal menu. Tapi menu yang disajikan cenderung sederhana. ${ }^{23}$ Namun makanan selalu tersedia setiap harinya.

\footnotetext{
${ }^{21}$ Beni Setiawan, Pengasuh Panti Asuhan Budi Mulya, Wawancara, tanggal 2 Juni 2015 2 Juni 2015

${ }^{22}$ Beni Setiawan, Pengasuh Panti Asuhan Budi Mulya, Wawancara, tanggal

${ }^{23}$ Misalnya mereka makan dengan menu nasi dan sayur, nasi dan tempe, ataupun tahu, telur, atau lainnya.
} 


\section{Ijtimaiyya: Jurnal Pengembangan Masyarakat Islam 10 (2) (2017)}

Dengan pengertian mereka rutin makan tiga kali sehari walaupun sederhana.

Biasanya setiap Senin dan Kamis mereka dianjurkan untuk melaksanakan ibadah puasa sunah. Pada saat berbuka dari ibadah puasa sunah Sunah Senin dan Kamis tersedia, lauk yang ditunggutunggu. ${ }^{24}$ Adapun menu istimewa biasanya ada di saat ada undangan dari simpatisan dan masyarakat. Biasanya mereka diundang saat dan acara santunan dan doa bersama pada acara atau kegiatan tertentu. Saat diundang ke rumah simpatisan dan masyarakat itulah mereka dijamu dengan hidangan istimewa. Di luar bulan Ramadan, biasanya undangan ini hanya sesekali saja. Namun di bulan Ramadan, undangan ini untuk berbuka puasa bisa jadi hampir setiap hari sepanjang bulan tersebut.

Kebutuhan pangan dan sandang mereka disiapkan berdasarkan kesanggupan panti. Hal ini tentu saja sangat bergantung pada bantuan dana dari persyarikatan Muhammadiyah, dinas sosial, dan dari donatur yang sifatnya suka rela dan tidak terikat. Donatur yang menyumbang untuk kebutuhan panti ini ada yang bersifat tetap dan donatur tidak tetap. Donatur tetap menyumbang secara rutin sedangkan donatur yang tidak tetap menyumbang secara temporal. Sumbangan yang diterima pantipun bisa beragam. Ada donatur yang memberikan uang, ada juga berbentuk barang. Ada kalanya berupa: beras, pakaian, bahan makanan, keperluan sekolah, dan lainnya. Semuanya diterima dengan tangan terbuka.

\section{Analisis Data}

Selanjutnya akan dianalisis permasalahan penelitian ini sebagai berikut:

Dalam Kompilasi Hukum Islam dijelaskan bahwa Hadhānah disebutkan yaitu: Pemeliharaan atau Hadhānah adalah kegiatan mengasuh, memelihara dan mendidik anak hingga dewasa atau mampu berdiri sendiri. ${ }^{25}$

Deklarasi Jenewa Tahun 1979 yang merupakan cikal bakal dari lahirnya Konvensi Hak-hak Anak PBB Tahun 1989. Di bagian I, pasal 7 dari deklarasi ini disebutkan secara ringkas dan tegas

${ }^{24} \mathrm{Menu}$ berbuka puasa biasanya tersedia ikan lele, tongkol, atau layang.

${ }^{25}$ Pasal 1 huruf (g) 
tentang hak-hak anak, bahwa: "sejak lahir setiap anak berhak atas perlindungan, pendidikan dan pemeliharaan baik secara material, keilmuan dan kultural yang wajib diberikan oleh orang tua, masyarakat dan Negara. Perhatian khusus juga wajib diberikan kepada janin dan ibu yang mengandungnya".

Dalam UUPA No. 23 Tahun 2002, Bab III Pasal 4 sampai dengan pasal 18, disebutkan hak-hak anak sebagai berikut:

a. Hak hidup, tumbuh dan berkembang

b. Hak memiliki nama sebagai identitas kewarganegaraan

c. Hak beragama dan berekspresi

d. Hak diasuh dan dibesarkan oleh orang tua sendiri

e. Hak kesehatan

f. Hak pendidikan

g. Hak didengar

h. Hak bermain

i. Hak mendapatkan perlindungan

Kebutuhan-kebutuhan dasar anak untuk tumbuh kembang yang optimal meliputi Asuh, Asih, dan Asah. Penjabarannya adalah sebagai berikut:

1. Kebutuhan fisik-biologis (asuh): Meliputi kebutuhan sandang, pangan, papan seperti: nutrisi, imunisasi, kebersihan tubuh dan lingkungan, pakaian, pelayanan kesehatan dan pengobatan, olahraga, bermain dan beristirahat.

2. Kebutuhan kasih sayang dan emosi (asih): Pada tahuntahun pertama kehidupannya (bahkan sejak dalam kandungan), anak mutlak memerlukan ikatan yang erat, serasi dan selaras dengan ibunya untuk menjamin tumbuh kembang fisik-mental dan psikososialnya.

3. Kebutuhan Stimulasi (asah). Anak perlu distimulasi sejak dini untuk mengembangkan sedini mungkin kemampuan sensorik, motorik, emosi-sosial, bicara, kognitif, kemandirian, kreativitas, kepemimpinan, moral dan spiritual anak.

Tentu saja dan yang terbaik bahwa pengasuhan itu dilaksanakan oleh kedua orang tua. Namun keadaan yatim, piatu, yatim piatu, ataupun dhu'afa menyebabkan sebagian anak-anak dala hal ini anak asuh di panti asuhan Budi Mulya harus terpisah dari orang tua dan keluarga mereka. 


\section{Ijtimaiyya: Jurnal Pengembangan Masyarakat Islam 10 (2) (2017)}

Kewajiban pengasuhan anak yang merupakan kewajiban dari orang tua kemudian dibantu untuk ditunaikan oleh pengurus dan pengasuh panti. Selama mereka menjadi anak asuh di panti asuhan tersebut. Pengurus dan pengasuh pantilah yang memfasilitasi seluruh kebutuhan hidup berupa pangan, sandang, dan papan. Memastikan mereka makan tiga kali sehari walaupun secara sederhana sesuai dengan kondisi keuangan dan kemampuan pengurus. Menyiapkan pakaian dan perlengkapan madrasah dan di panti. Mulai dari pakaian sekolah, pakaian sehari-hari, pakaian salat, sepatu, buku-buku pelajaran, peralatan makan, peralatan mandi, dan seterusnya. Dan tentu saja menyiapan tempat tinggal yang nyaman dan memadai sesuai dengan standar kesehatan.

Selain kebutuhan fisik, pengurus dan pengasuh panti juga berusaha memenuhi kebutuhan mental spritual mereka. Mereka bersekolah di madrasah secara formal. Kemudian sekembalinya mereka dari madrasah, sepenuhnya tanggung jawab diambil alih oleh pihak panti asuhan.

Pengurus dan pengasuh panti beserta para anak asuh merupakan sebuah keluarga. Pengasuh panti beserta para anak asuh tinggal dalam komplek panti asuhan. Adapun pengurus tinggal di luar panti. Namun pengurus dan pengasuh berusaha semaksimal mungkin memberikan pembinaan para anak asuh. Para pengasuhlah yang mengasuh dan membina para anak asuh dalam menjalani kehidupan mereka di panti. Memberikan contoh dan teladan yang baik bagi para anak asuh dalam beribadah dan berlingkah laku dengan mengawasi serta mengontrol peri laku mereka sepanjang waktu.

Para mengasuh juga berusahan pemahami potensi-potensi yang dimilki oleh para anak asuh. Pentung untuk memahami potensi dari masing-masing anak asuh. Dengan memberikan kesadaran pada potensi, bakat, dan talenta yang dimiliki oleh anak, maka potensi itu dapat dibina dan dikembangkan sebagai bekal bagi mereka nantinya.

Faktor Pendukung adalah faktor yang menjadikan pengurus dan pengasuh termotivasi atau rasa sukanya mengurus dan mengasuh anak yatim di Panti Asuhan Budi Mulya, yaitu:

a. Niat pengabdian yang tulus yang ikhlas. Tidak banyak orang yang mau berkecimpung langsung atau menjadi pengasuh anak yatim atau anak terlantar/ tidak mampu, baik di rumah 
maupun di panti asuhan. Tentunya hanya mereka yang punya niat yang tulus ikhlas untuk pengabdian kepada sesama. Jajaran kepengurusan dan pengasuh panti asuhan tentunya hanya dengan niat yang tulus ikhlas untuk pengabdian, kepedulian terhadap nasib mereka yatim, piatu, tidak mampu, yang sesungguhnya mereka adalah generasi penerus bangsa.

b. Menjaga amanah. Mengasuh anak yatim dibutuhkan pribadi amanah artinya mengasuh anak yatim dengan memahami dan memenuhi hak atau kewajiban, psikologi perkembangan, tugas-tugas perkembangan, dan tidak menerlantarkannya. Apalagi sampai menyelewengkan, memakan harta, dan memperalatnya. Tantangan pengurus adalah bagaimana bisa membawa tugas ini sebagai amanah. Karena dari sisi materi, jumlah bantuan untuk panti asuhan cukup banyak, untuk berbuat curang/ tidak amanah sangat mudah, misalnya ada dermawan yang berinfak tetapi tidak mau diberi kuitansi/ tanda bukti berinfak. Maka di sini tantangan pengurus untuk tetap membawa amanah.

c. Dukungan Masyarakat. Eksistensi Panti Asuhan Budi Mulya tidak lepas dari peran serta masyarakat. Salah satu syarat pendirian panti asuhan adalah dukungan masyarakat. Peran masyarakat sangat diperlukan demi kelangsungan hidup mereka. Bukti peran serta aktif masyarakat secara umum, bukan hanya masyarakat di sekeliling panti asuhan tetapi juga kaum muslin secara umum adalah mereka sering memberikan bantuan baik materi maupun spirit. Karena panti asuhan Budi Mulya ini telah dikenal secara luas oleh masyarakat.

d. Sarana. Sarana merupakan faktor penting yang demi terlaksananya kegiatan di panti asuhan. Komplek panti asuhan Budi Mulya dapat dikatakan cukup baik. Di Komplek ini berdiri madrasah Tsanawiyah Muhammadiyah dan madrasah Aliyah Muhammadiyah. Adapun madrasah Ibtidaiyah Muhammadiyahnya hanya berjarak 100 meter dari komplek tersebut. Terdapat kamar-kamar tidur, ruang makan, kamar-kamar mandi, dapur umum, masjid, kantor panti asuhan, dan halaman yang cukup luas. Semua 
298 ljtimaiyya: Jurnal Pengembangan Masyarakat Islam 10 (2) (2017)

bangunan-banguan tersebut adalah milik sendiri, milik persyarikatan Muhammadiyah.

Semua bangunan tersebut permanen. Semua bangunan tersebut merupakan wakaf dari kaum muslimin. Bahkan dengan perkembangan kedua madrasah tersebut, sedang dilaksanakan pembangunan ruangan kelas yang baru guna menampung siswa siswi di kedua madrasah tersebut.

e. Sumber Dana. Sumber dana panti asuhan Budi Mulya Sukarame dipusatkan di Bendahara yang berasal dari:

1) Bantuan donator berupa zakat, infak, sedekah dan bantuan lainnya yang tidak mengikat.

2) Bantuan dari instansi pemerintah: Kementrian sosial RI, dinas sosial propinsi Lampung, dan dinas sosial kota/ kabupaten di provinsi Lampung

3) Usaha produktif yang dilakukan oleh panti asuhan. ${ }^{26}$

Di samping ada faktor pendukung tak terlepas juga faktor penghambat atau kendala yang dihadapi oleh pengasuh, antara lain:

a. Anak asuh. Ketika anak masuk di panti asuhan tidak semuanya langsung kerasan, mereka membutuhkan waktu untuk adaptasi di lingkungan dan teman baru yang belum dikenal. Peran pengasuh sangat penting untuk memberikan arahan dan motivasi agar mereka kerasan. Ketika motivasi dan arahan sudah diberikan dan mereka tetap tidak kerasan, sehingga kemudian terdapat anak asuh yang keluar dan dikembalikan kepada orang tuanya. Menurut pengasuh sebagian mereka yang tidak kerasan biasanya dipaksa untuk dikirim ke panti asuhan oleh keluarganya. Atau mereka merasa tidak bebas karena terikat dengan kegiatan dan peraturan panti asuhan, yang kontras kondisi mereka di rumah.

b. Masalah lainnya adalah beragamnya latar belakang keluarga dan tingkat kecerdasan para anak asuh menyebabkan sulitnya dalam mewujudkan program kerja yang telah digariskan. Beni Irawan menyatakan beragamnya latar belakang para anak asuh menjadi salah satu faktor penghambat

\footnotetext{
${ }^{26}$ Statuta Panti Asuhan Budi Mulya Muhammadiyah Sukarame, Tahun 2007, pasal 23
} 
menerapkan aturan yang ketat ataupun menjalankan dan menyelenggaraan panti asuhan Budi Mulya dengan atau secara model pondok pesantren yang ditegaskan dalam Statuta panti asuhan Budi Mulya. ${ }^{27}$

c. Pelaksanaan model pondok pesantren di panti asuhan Budi Mulya secara sempurna dikhawatirkan akan banyak anak asuh yang tidak dapat mengikutinya dengan baik. Sehingga model pesantren yang diterapkan tidak seperti yang seharusnya. Minimal mereka dapat:

1) Beribadah dengan baik, seperti: salat lima waktu, membaca al-Qur'an, doa-doa sehari-hari, dan pembelajaran puasa.

2) Mendapatkan pendidikan secara formal di Madrasah Ibtidaiyah Terpadu, Madrasah Tsanawiyah Muhammadiyah Sukarame, atau Madrasah Aliayah Muhammadiayah Sukarame.

d. Pengasuh yang belum profesional. Jumlah pengasuh di panti asuhan tujuh belas orang. Terdiri dari dua pasangan ustadz dan ustadzah; yang merupakan pasangan suami dan istri dan tiga belas lainnya masih berstatus mahasiswa. Mereka yang terakhir ini adalah mantan anak asuh di panti asuhan Budi Mulya yang telah menamatkan pendidikannya di Madrasah Aliyah Muhammadiyah. Dengan pengertian mereka telah menjadi alumni. Ketika mereka melanjutkan pendidikannya secara mandiri, ${ }^{28}$ mereka tetap tinggal di panti asuhan dan status mereka sekarang adalah sebagai pengasuh. Status mereka sebagai mahasiswa ini menyebabkan mereka belum atau tidak bisa melaksanakan tugasnya secara profesional. Namun pengalaman mereka pernah menjadi anak asuh cukup membantu para ustadz senior dalam melaksanakan tugas pengasuhan dip anti asuhan Budi Mulya.

Menurut pengamatan yang peneliti lakukan, mereka bertugas membantu pasangan ustadz dan ustadzah dalam melaksanakan tugas pengasuhan di panti asuhan. Baik itu dalam memastikan setiap anak asuh itu mengikuti setiap

${ }^{28}$ Yang biasanya disupport oleh keluarga besarnya di kampong. 
300 Ijtimaiyya: Jurnal Pengembangan Masyarakat Islam 10 (2) (2017)

kegiatan-kegiatan yang dicanangkan, melaksanakan aktifitas harian dengan baik, mematuhi disiplin panti, membantu administrasi panti dan sebagainya.

e. Struktur kepengurusan yang belum bekerja maksimal. Modal utama mengurus panti asuhan adalah ketulusan dan keikhlasan. Sebagaimana diungkapkan Thabroni Zuhri bahwa kepengurusan panti asuhan Budi Mulya sekarang cenderung belum berjalan dengan baik. Sehingga hanya sebagaiannya saja yang bekerja sebagaimana amanah yang telah dititipkan kepada mereka. Hal ini diduga mereka harus bekerja untuk kehidupan keluarganya sehingga tidak memiliki waktu dan kesempatan untuk menjalankan tugasnya sebagai pengurus panti asuhan.

Sehingga dari hasil penelusuran data-data terkait administrasi dan pembukuan di panti asuhan Budi Mulya belum tertata dengan baik. Hal ini tentu saja terkait dengan kahadiran dan pelaksanaan tugas oleh para pengurusnya.

Selanjutnya tugas-tugas administrasi ini dibantu oleh para pengurus dari kalangan mahasiswa tadi. Kemungkinan tidak adanya petunjuk dan arahan yang jelas, sehingga tugas administrasi ini belum berjalan secara maksimal. Tugas mereka cenderung hanya melakukan pendataan bantuan-bantuan yang datang atau dikirim ke panti asuhan.

\section{Kesimpulan} berikut:

Dari paparan sebelumnya, dapatlah kita simpulkan sebagai

1. Panti asuhan Budi Mulya Muhammadiyah telah membantu untuk menunaikan kepengurusan dan kepengasuhan anak asuh. Tugas ini dikasanakan selama mereka menjadi anak asuh di panti asuhan tersebut. Merekalah yang mengambil alih kewajiban pengasuhan anak yang merupakan kewajiban dari orang tua. Pihak panti memfasilitasi seluruh kebutuhan dasar anak asuh berupa: pangan, sandang, dan papan. Mereka juga menyiapkan pendidikan formal dan non formal bagi mereka. Tidak lupa mereka juga dibekali 
pengetahuan dan pengamalan ibadah praktis sehari-hari. Semua ini sebagai bekal kehidupan dunia dan akhirat.

2. Faktor Pendukung adalah faktor yang menjadikan pengurus dan pengasuh termotivasi atau rasa sukanya mengurus dan mengasuh anak yatim di Panti Asuhan Budi Mulya, yaitu:

a. Niat pengabdian yang tulus yang ikhlas dari pengurus dan pengasuh panti asuhan Budi Mulya .

b. Pengurus dan pengasuh panti asuhan Budi Mulya menjaga amanah yang diberikan.

c. Dukungan Masyarakat.

d. Sarana prasarana yang baik.

Di samping ada faktor pendukung tak terlepas juga faktor penghambat atau kendala yang dihadapi, antara lain:

1. Anak asuh besasal dari berbagai kalangan yang berbeda.

2. Pelaksanaan model pondok pesantren di panti asuhan Budi Mulya yang tidak berjalan dengan baik.

3. Pengasuh yang belum profesional.

4. Struktur kepengurusan yang belum bekerja maksimal. 


\section{Daftar Pustaka}

Abdul Azis Dahlan, Ensiklopedi Hukum Islam, Jakarta: Ikhtiar Baru Van Hoepe, 1999

Al-Sayid Sabiq, Fiqh al-Sunnah, Beirut: Dar Kitab al-Arabi, 1987

Andi Syamsu Alam dan M. Fauzan, Hukum Pengangkatan Anak Perspekftif Islam, Jakarta: Pena Media, 2008

Deliar Noor, Gerakan Modern Islam di Indonesia 1900-1942, (Jakarta : LPE3S, 1980

Imam Abu Hamid Muhammad bin Muhammad al-Gazali, Ibya Ulum ad-Din, Beirut: Dar al-Fikr, 1995

KompilasiHukum Islam (KHI)

Mushthafa az-Zuhaili, Huquq al-Aulaq 'ala al-Walidain fi asSyari'ah al-Islamiyah, tt.

Nurwahidah, Kejahatan Terhadap Anak dan Solusinya Menurut Hukum Islam, Syariah Jurnal Ilmu Hukum, Volume 15, Nomor 2, Desember 2015

Undang-undang No. 1 Tahun 1974 Tentang Perkawinan 